\begin{tabular}{ll}
\hline 論 & 説 \\
\hline
\end{tabular}

\title{
先天性外耳道狭窄症は危険な病態である
}

一診断と対応の仕方一

\author{
山根 英雄 - 高山 雅裕 - 角南貴司子 - 椅野 理恵 \\ 森中 幹仁・小島 道子・ 中村 訓子
}

\section{Congenital External Auditory Canal Stenosis: A Serious Disease Leading to Destruction of the Mastoid Cavity}

\author{
-Its Diagnosis and Treatment- \\ Hideo Yamane, Masahiro Takayama, Kishiko Sunami, Rie Tochino, \\ Mikihito Morinaka, Michiko Kojima and Kuniko Nakamura \\ (Osaka City University Graduate School of Medicine)
}

\begin{abstract}
Congenital external auditory canal stenosis (CAS) is usually considered one of the slight malformations related to congenital external auditory canal atresia (CAA). However, the clinical symptoms caused by the slight malformation may not be mild. Destructive external ear canal cholesteatoma commonly occurs in CAS, but is infreguent in CAA. For several reasons CAS tends to receive an inappropriately low estimate of risk compared to that for CAA. The other malformations accompanying CAS and CAA such as microtia confound the decision regarding future treatment for doctors as well as for the patients themselves. A consensus regarding the clinical entity of CAS is required among doctors not only in otorhinolaryngology but also in relevant fields such as pediatrics and plastic surgery. These two malformations, the pathological conditions and clinical treatment of CAS and CAA should be considered separately.
\end{abstract}

Key words : congenital external auditory canal stenosis, congenital external auditory canal atresia, external ear canal cholesteatoma, surgery

はじめに

先天性外耳道狭窄症は先天性外耳道閉鎖症の分類の中 では軽度な形成異常に属している．形成異常が軽度であ ることは臨床症状が軽微であるということではない.

ネルソンの小児科学 ${ }^{1)}$ においては「先天性外耳道閉鎖 症や狭窄症には耳介や中耳の奇形が伴らことがある. (以 後, 中略) 軽度の先天性外耳道狭窄症においては慢性外 耳炎や聴覚に影響するほどひどい耳垢栓塞を起こしてい ない限り，外科的に拡張する必要はない. 先天性外耳道
閉鎖症に対する外耳道と中耳の再建手術は, 一般に両側 性の場合で伝音難聴の高度な 5 歳以上の小児において考 慮される.」と記載されている.この中での軽度といら言 葉は後述するが，曖昧かつ誤解を生むものである.

一方, 形成外科学の欧米の種々の書物の記載2)3) では, 耳介の奇形に対する手術の項目はあるのだが，外耳道の 項目はほとんどみあたらない，外耳道形成過程における 先天異常は, 後述のごとく, 小耳症に代表されるように 他の奇形も合併することがある。 その外観から形成外科 
学的には上記当該科の医師にとって, また, 患者にとっ てもこれら合併する病態の方が先天性の外耳道の形成異 常より重篤とみなされらる。 またこれら 2 疾患は程度の 差こそあれ，同じ臨床病態であると解釉されてしまら可 能性もある。すなわち，これらの書物からでは疾患の差 にかかわらず，一側性の先天性の外耳道の異常に対して は手術は基本的には必要ではないと判断されてしまら可 能性がある。しかし,これら 2 疾患は臨床的には全く違っ た様相を呈する，以下，先天性外耳道狭窄症の存在が過 小評価された症例を提示しながら先天性外耳道狭窄症の 問題点を述べてみる.

\section{咽頭器官の発生}

胎生 4 週頃に咽頭弓（図 1）が発生するが，耳介を含 めた外耳，中耳などの原器が関係するのは第 I，第 II 咽 頭（鰓）弓，第 I 咽頭（鰓）溝，第 I 咽頭（鰓）膜，第 I 咽頭（鰓）囊である ${ }^{4)}$. 外耳道の管空化は胎生 $26 \sim 28$ 週頃に完成されるが，先天性外耳道閉鎖症はこの管空化 不全, すなわち胎生期の第 I 咽頭溝の陥凹で生じる外耳 道栓の管空化不全により生じたものである（図 2)。第I 咽頭溝は第 I 咽頭弓と第 II 咽頭弓の間に位置する部分で あるのでこれら 2 弓の形成異常が先天性外耳道閉鎖症に

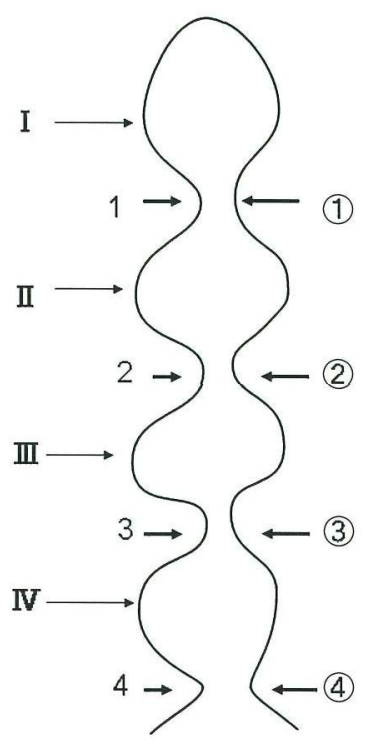

図 1 咽頭器官の発生

I IV : 各咽頭弓 $\quad 1 \sim 4$ : 各咽頭溝 (1) (4)：各咽頭囊

合併する場合がある、第 I 咽頭弓（下顎弓）からは下顎 骨, 上顎骨, 㚘骨, 側頭骨鱗部が生じるのでその異常は 顔面形成不全として認められる。一般には第 I 咽頭弓軟 骨（メッケル軟骨）からは下顎骨，ツチ骨，キヌタ骨，
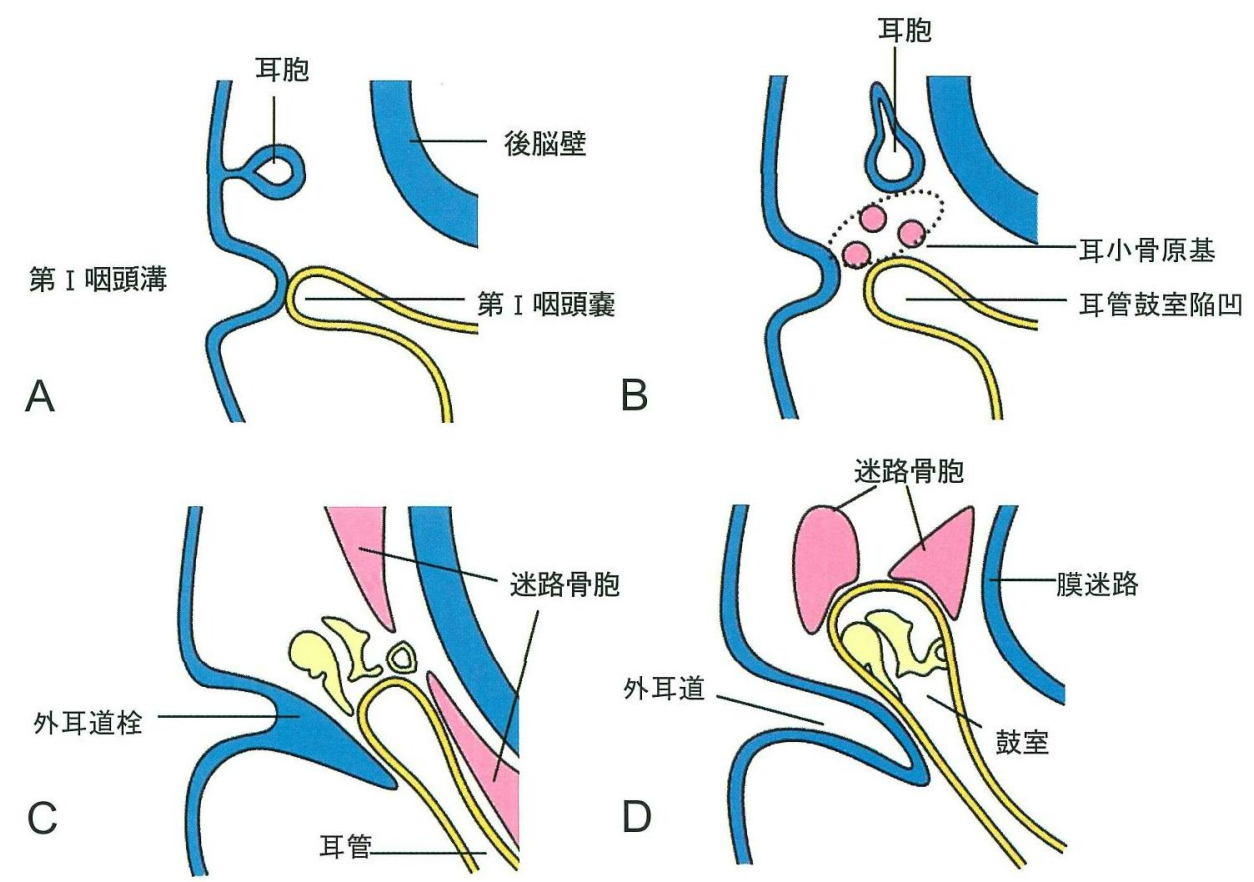

図 2 外耳と中耳の発生 (Moore KL ら ${ }^{4)}$ より改変)

$\mathrm{A}$ : 胎生第 4 週 $\mathrm{B}$ : 胎生第 5 週 $\mathrm{C}$ : 胎生 3 力月 $\mathrm{D}$ : 胎生末期 
第 2 咽頭弓軟骨（ライヘルツ軟骨）からはアブミ骨が発 生すると考えられている．第I 第 II 咽頭（鰓）弓症候群 (眼球耳介椎骨形成不全症)には重症型としてゴールデン 八一症候群（眼臉の類上皮腫と，脊椎奇形を含む）が知 られるが，その他種々の程度の形成異常が存在する場合 がある、第I および第 II 咽頭弓に由来する耳介小丘から は耳介が形成されるのでその異常はいわゆる小耳症とし ても認められる。第 I 咽頭 (鰓) 弓症候群としてはトリ一 チャーコリンズ症候群，ピエールロバン症候群などがよ く知られるところである。本稿では先天性外耳道狭窄症 を第I咽頭溝の異常と再認識してその重要性を記述する。

\section{先天性外耳道狭窄症はなぜ危険なのか}

先天性外耳道閉鎖症と先天性外耳道狭窄症との臨床解 剖的な大きな違いは前者は基本的には閉鎖板の外側には 間隙が存在しないが後者には存在するといらことである (図 3)。このことがこの間隙を有する先天性外耳道狭窄 症にいわゆる閉塞性真珠腫が発生する原因となって いる。一方，この間隙を有さない先天性外耳道閉鎖症 には外耳道真珠腫の発生はきわめて少ない.1989 年の
Schuknecht ${ }^{5)}$ の報告によると, 先天性外耳道狭窄症 7 例中 全例に，また，部分的に外耳道がやや狭くなった症例 11 例中 2 例に外耳道真珠腫が生じていたが, 先天性外耳道 閉鎖症 51 例中においては1例にのみ外耳道真珠腫が生じ ていたという。すなわち，先天性外耳道狭窄症は先天性 外耳道閉鎖症より断然，閉塞性の外耳道真珠腫が生じる 傾向の強い危険な病態なのである.

これに関してはかなり誤解の生じる記載があるように 思える. Ombredanne ら ${ }^{6)}$ は，彼らのいう高度の外耳道 奇形 (外耳道閉鎖症) の患者 330 人のらち 10 人に外耳道 真珠腫を認めている.Peron ら7)によれば，1912 年から 1969 年までの外耳道閉鎖症の報告の中で 20 例に外耳道 真珠腫を認めている. CT 像がないので断定できないが, 記載から判断するとこれらのかなりの症例が先天性外耳 道閉鎖症ではなく，外耳道狭窄症と思われる。これらの 報告に汃かわらす，過去の報告には外耳道閉鎖症と外耳 道狭窄症を用語上，厳密に区別して記載していない可能 性がある ${ }^{8)}$ 。また，外耳道真珠腫がかなり進展した症例 では骨破壊が進多，発生母体が外耳道閉鎖症か，狭窄症 かの判断が難しくなっていることなどが誤解を生み出す
A

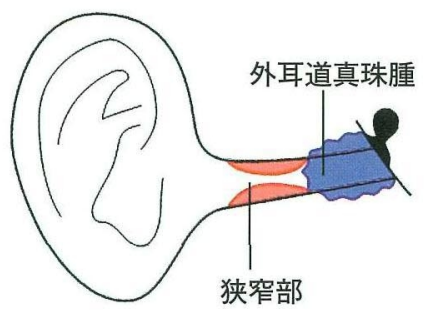

B

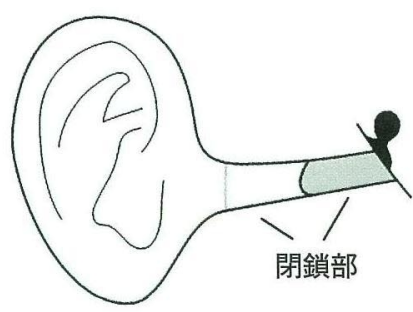

C

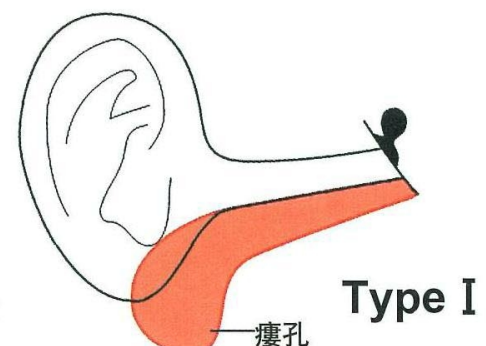

D

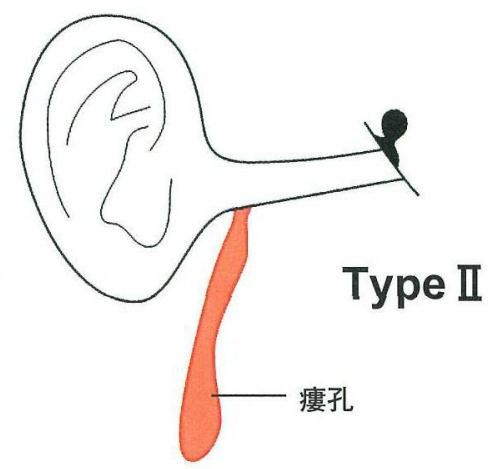

図 3 第 I 咽頭溝の種々の形成異常

$\mathrm{A}$ ：外耳道狭窄症 内部に外耳道真珠腫が形成されている. B : 外耳道閉鎖症

C, D : 重複第 I 咽頭溝による瘦孔形成で type I と type II がある. 


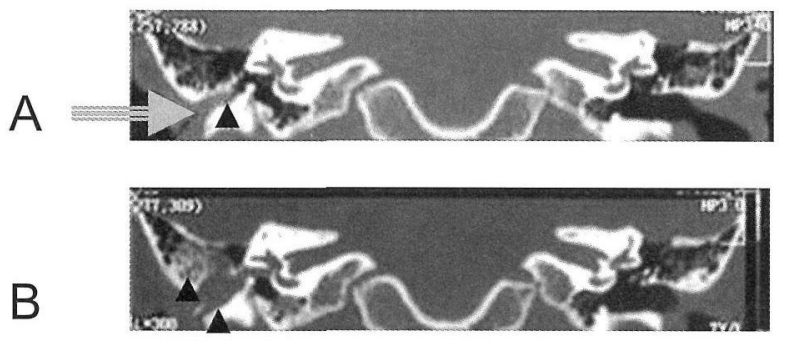

図 4 症例 $1: 7$ 歳女児 (先天性外耳道狭窄症) の側頭骨 CT 所見 $\mathrm{A}$ ：当科受診の 7 力月前 右外耳道の狭窄と外耳道真珠腫 (矢印) が認められる。 外耳道骨には炎症による肥厚と浸潤（矢頭）が認めら れる。

$B$ ：当科受診時

右外耳道真珠腫は7カ月前に比べてかなり進展してい る (矢頭)。

原因になっていると思われる。

さて, 先天性外耳道狭窄症で耳症状が出現して医療機 関に受診した時点では真珠腫がすでにかなり進展してい ることが多いので注意が必要である。この外耳道真珠腫 は年齢とともに進展し20歳以上の例ではほとんどすべて が破壊的である。特に外耳道入口部の径が小さい場合は 要注意であり， $2 \mathrm{~mm}$ 以下の場合は $59 \%$ (26/39人) に 外耳道真珠腫が存在しているとの報告がある ${ }^{9)}$.

以下に代表的な症例を提示する。

症例 1

7 歳の女児で右耳に 1 度の小耳症があり, 2 年前に形成 手術が行われている。当科受診の7カ月前より右耳漏が 出現し，来科時には右乳様突起炎が認められた。当科で の側頭骨 CT 像では右外耳道狭窄に伴ら外耳道真珠腫の 浸潤による乳様突起炎であった。当科受診の 7 力月前の 側頭骨 CT 像ではすでに外耳道真珠腫が認められている が気付かれていなかった（図 4)。

症例 2

9 歳の女児で右耳に 1 度の小耳症があり 3 年前に形成 手術が行われている。

当時の側頭骨 CT 像では右外耳道狭窄に伴う外耳道真 珠腫が認められるが，気付かれなかった。当科受診まで にすでに 2 回の右乳様突起炎を起こしている。本症例で は症例 1 に比べて真珠腫の浸潤, 骨破壊が高度である(図 5).

\section{なぜ外耳道狭窄症が過小評価されるのか}

Shah ${ }^{10)}$ によれば,外耳道閉鎖症の記載は 17 世紀にみら れ，1882 年 Kieselbach により初めて手術がなされたが， 術後, 顔面神経麻痺を残している。

その後も外耳道閉鎖症の手術が行われはしたが，外耳 道を形成するのみで終わることが多く, 聴力の改善に関 しては期待すべくもなかったようである，今までに，恥 力改善をも目的として種々の手術が行われてきたにもか かわらず，満足のいくべき結果を得ていないのが現状で ある11)。このことが, 副損傷をはじめ術後の状態, 患者 の満足度などから, 現在, 他科のみならず, 耳鼻咽喉科 においても外耳道閉鎖症は無理をしてまでの積極的な治 療を要しない疾患と考えられている一つの原因になって いる。 ましてや外耳道狭窄症に至ってはその存在感は外 耳道閉鎖症以下といってもよいほどである，以下に，な ぜ，外耳道狭窄症が軽視されるのかを列記する。

(1)分類の問題

外耳道閉鎖症の分類に関しては種々あるが，よく知ら れているのは 1955 年の Altmann の分類である (表 1) ${ }^{12)}$. 疾患の重症度を種々の因子をも含めているが，主として 外耳道の開存度の状態をもってグループをIから III に分 類している. De La Cruz の分類 ${ }^{13)}$ は中耳腔や内耳の異常 状態で外耳道閉鎖症を軽度と高度に分けているが，この 分類においても発生学的な観点加ら先天性外耳道狭窄症 は結果的に軽度の異常に属してしまう。一方, Schuknecht の分類 ${ }^{5)}$ はわかりやすく, 先天性外耳道狭窄症と先天性 外耳道閉鎖症の分類は臨床的な観点をるまえているが, 順序づけからすれば， A 〜 D に向から高度異常の分類に おいて先天性外耳道狭窄症は軽度な Bタイプに属してい る. 先天性外耳道閉鎖症の手術の必要性が高くない観点 からすれば，このような分類から判断される先天性外耳 道狭窄症の立場はさらに軽視されるのは理解されるであ ろら.

\section{(2)合併症の問題}

前述のごとく第 I 咽頭溝異常による疾患は第 I および 第II咽頭弓の異常が伴うことが多くそれらは外観的には 重篤な形成異常であり，そちらへの対応が優先され先天 性外耳道狭窄症や先天性外耳道閉鎖症は二の次になって いる可能性がある。

(3)手術の問題

先天性外耳道閉鎖症，狭窄症の手術は耳科手術の中で は難易度の高い手術であり, 顔面神経の走行異常や, 中 

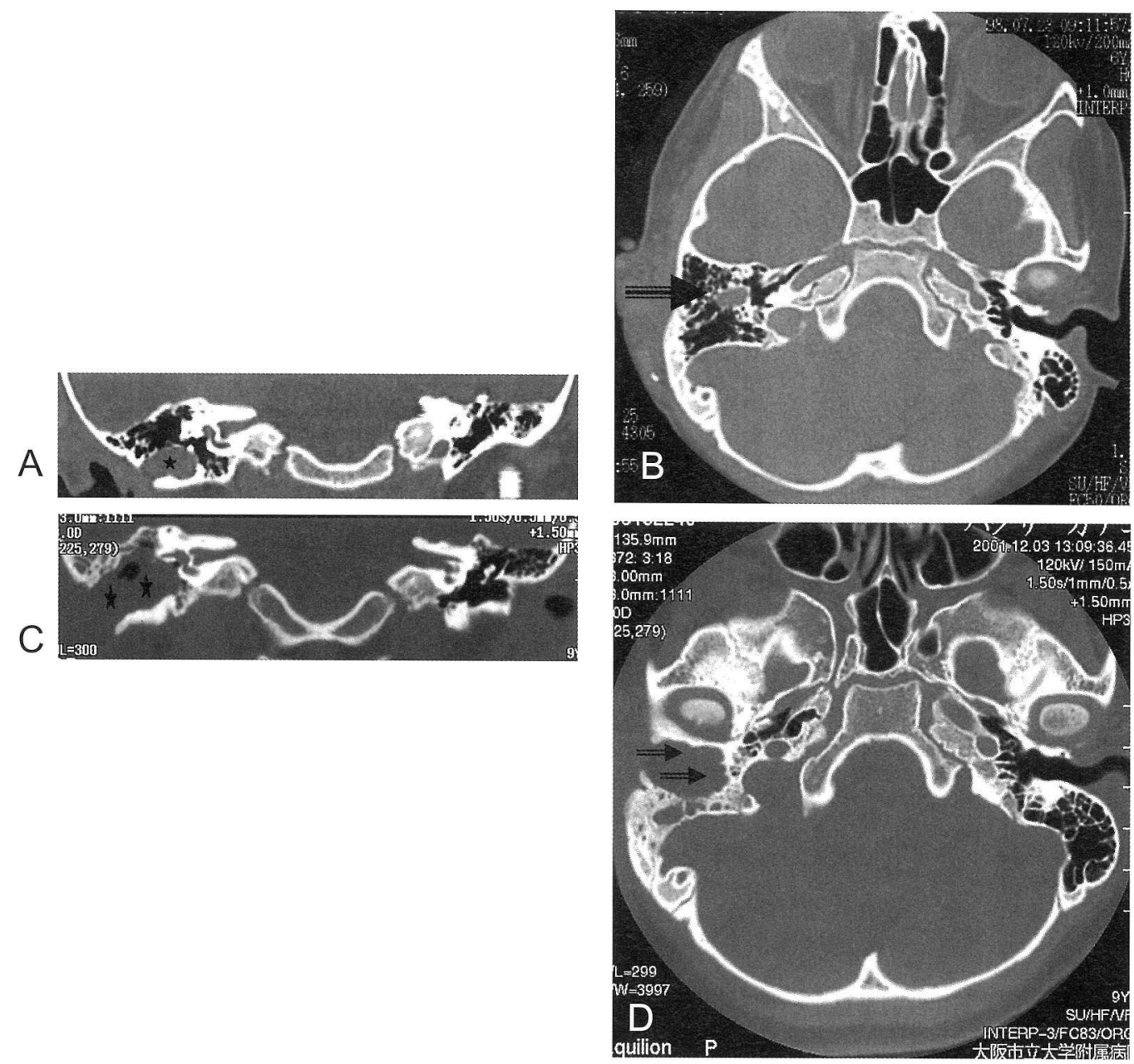

図 5 症例 2:9 歳女児（先天性外耳道狭窄症）の側頭骨 CT 所見
A, B : 小耳症手術時（当科受診の 37 力月前）
右外耳道の狭窄と外耳道真珠腫（星印と矢印）が認められる.
$C, D$ : 当科受診時
右外耳道真珠腫は症例 1 より破壊的にかなり進展している（星印と矢印）。

表 1 Altmannの先天性外耳道閉鎖症の分類（Altmann $\mathrm{F}^{12)}$ より改変）

\begin{tabular}{|c|c|c|}
\hline Group & degree of anomaly & Conditions \\
\hline Group I & mild & $\begin{array}{l}\text { small external ear canal, hypoplasstic tympanic bone and tympanic membrane with } \\
\text { normal or small tympanic cavity }\end{array}$ \\
\hline Group II & moderate & $\begin{array}{l}\text { absent external ear canal with atretic plate, small middle ear space, malleus and incus } \\
\text { fixed and malformed }\end{array}$ \\
\hline Goup III & severe & $\begin{array}{l}\text { includes those with abscent external ear canal with contracted or abscent middle ear } \\
\text { with or without ossicles }\end{array}$ \\
\hline
\end{tabular}

耳奇形の合併は術中の副損傷につながる可能性がある. 聴力の改善はらまくいっても，気導骨導差は $30 \mathrm{~dB}$ 前後 にとどまる。をた, 術後, 新生外耳道の再狭窄, 外耳・
中耳の感染, 聴力の再低下などが少なからず伴う。一方, 術後の患者の満足度は納得いくものであろうかといら問 題がある。 
(4)他科のとらえ方の問題

冒頭のごとく小児科, 形成外科領域における書籍の記 述などから先天性外耳道狭窄症は過小評価につながって いると考えられる。

\section{第 I 咽頭溝異常による他の疾患}

先天性外耳道狭窄症は先天性外耳道閉鎖症と同じく, 第 I 咽頭溝の発生異常による疾患ではあるが，それ以外 に臨床的に遭遇する代表的な疾患として, 重複第 I 咽頭 （鰓）溝（Duplication anomaly of first branchial groove）が ある14)15）(図 3)。これには type I（I 型），type II（II 型） の区別がある．また，重複第 I 鰓溝に先天性外耳道閉鎖 症が合併する症例も報告されている ${ }^{16)}$. 外耳道形成過程 における先天異常は，上述のごとく，第 Iおよび第 II 咽 頭弓の狭間の部位の形成異常であるのでこれら咽頭弓の 形成異常が合併することがあるので留意する必要があ る.

\section{検 査 法}

疾患の性質上，生下時よりその存在が確認できる。す なわち，外耳道の閉鎖や狭窄および小耳症などが合併す る場合があることからその存在は明らかである.しかし， 視診のみにおいては十分ではない，外耳道の詳細な情報 は把握できず見過ごされる可能性があるので, 側頭骨 CT 撮影が必要である.外見上の問題以外に大きな問題点は, 今後, 言語の獲得に支障をきたさないか, 耳性合併症が おこる危険性があるか否かである。その意味でも，純音 聴力検查（乳幼児であれば $\mathrm{ABR}$ や乳幼児聴検）で聴力 の把握と側頭骨 CT 撮影は必須である.

\section{診断のポイントと鑑別診断}

聴力検查から約 $60 \mathrm{~dB}$ 程度の伝音難聴があれば先天性 外耳道閉鎖や狭窄症，およびそれに伴う耳小骨の形成異 常の存在む考慮に入れる必要がある. 側頭骨 CT 画像か らは外耳道の閉鎖が確認できる. CT 画像による先天性 外耳道閉鎖症と先天性外耳道狭窄症との鑑別は比較的容 易であり, 後者の場合, 外耳道真珠腫の存在の確認も容 易である（図 4，5）。外耳道真珠腫の存在している部位 の外耳道の骨は肥厚していたり浸食されていることが多 い. 外耳道真珠腫が進行している場合, 耳介周囲の治り にくい炎症や㾇孔形成が認められることもある。重複第 I 鰓溝（duplication of 1st branchial groove）も（図 3)，側
頭骨 CT 画像で容易に鑑別できる。この疾患の症状は先 天性外耳道狭窄症と同じく, 治りにくい耳介周囲の炎症 や瘦孔形成で認められることが多い，CT 画像による I 型, II 型の鑑別に加えて外耳道閉鎖症, 狭窄症ではない という除外診断む必要である. I 型は軟骨部外耳道の重 複奇形であり, II 型は軟骨部外耳道と耳介の重複奇形で ある. I 型は耳後部周囲に囊胞を形成し, 正常の外耳道 近くを走行し骨部外耳道に終わっている. 基本的には耳 介周囲や頸部への瘦孔形成はない. II 型は胸鎖乳突筋前 縁に沿っての上頸部に瘦孔形成を生じる. 先天性耳瘦孔 も耳介周囲の炎症や瘦孔形成など一見, 上記疾患と類似 の症状を呈することもあるが, 病巣出現部位からしても 先天性耳瘻孔の診断は容易である.

\section{ビう対応するのか}

別稿でも叙述はしたが ${ }^{11)}$ ，小耳症は形成外科医，外耳 道狭窄症を含めて鼓室形成術は耳鼻咽喉科医の専門領域 と端的に分けて考えれば本疾患に対する対応の誤解は生 じにくいであろう。

1. 先天性外耳道狭窄症

顔面骨の形成異常や術前の手術結果を予測する Jahrsdoerfer ら 17) のスコアーを参考にする必要はあるが, 基本的には，破壊的な真珠腫が合併していることが多い ので早めの手術を行うのが第一選択である。言語獲得の 面から骨導補聴器の選択は一時的にはあっても, 恒久的 にはありえない. 手術を行う場合, 他の外耳, 中耳奇形 が合併している場合があり，その対応にも留意する必要 がある.すなわち小耳症の合併の程度, 中耳奇形の程度 (顔面神経の走行異常がある場合も含む) と術者の熟練度 で手術方法が変わる．現在，論じられることが多いのは 手術アプローチの方法と術後の再建外耳道の再狭窄防止 の手技である．先天性外耳道閉鎖症には種々の手術アプ ローチが報告されている. anterior アプローチ (one tunnel 法) ${ }^{13)}$, posterior アプローチ (経乳突洞法) ${ }^{13)}$, 両アプ ローチを併用した combined アプローチ18) などである. これらは術操作の安全性や, 術後経過などの手術成績か ら考案された方法であり, 基本的には先天性外耳道狭窄 症も先天性外耳道閉鎖症の手術と同じアプローチ，同じ 手技が行われることが多い，術者の得意なアプローチを 選択すれば良いのではあるが，先天性外耳道狭窄症には 真珠腫が合併していること, 術中の合併症の回避，患者 年齢が若いことなどを考慮に入れて手術方法を選択する 
必要がある.われわれは, 術中の安全性の確認, 真珠腫 の完全除去, 術後の再建外耳道の再狭窄防止の観点から Transmastoid アプローチ変法19) を考案し良好な成績を得 ている.

\section{2. 先天性外耳道閉鎖症}

1) 先天性外耳道閉鎖症の場合は, 生後数力月に聴力検 查が行われ, 両側性の場合は 6 カ月からの聴能訓練の必 要性が20)ある.

2) 片側性の場合，片側の聴力のみでは方向感の同定の みならず言語獲得に不利といら報告21) もあるが, 他側が 正常なのであえて手術の適応はない，両側性の場合，す でに $60 \mathrm{~dB}$ 程度の伝音難聴があることから, 特殊な場合 を除き，ほぼ全例が言語発達の面から早期に骨導補聴器 を装着する必要がある

\section{治療予後}

先天性外耳道狭窄症と違い, 先天性外耳道閉鎖症には 外耳道真珠腫の合併は少なく, 骨導補聴器を使用する場 合においては特別に問題になることはない，手術治療を 行う場合, 一般の中耳手術と同様の副損傷の可能性が考 えられるが, 先天性外耳道閉鎖症, 狭窄症には顔面神経 の走行異常がある場合があり, 特に注意が必要である. 術後の問題点としては術後の新外耳道の再狭窄, 鼓膜の 浅在下による聴力の再低下, 外耳, 中耳感染, 真珠腫の 発生などであり,再手術が必要となる場合が少なくない.

\section{おわりに}

先天性外耳道狭窄症は分類上は先天性外耳道閉鎖症の 軽度の形成異常に属するが，両者は臨床的対応の面から 分けて考える必要がある. 先天性外耳道狭窄症は軽度の 形成異常にもかかわらず臨床的には実は大変危険な病態 なのである. 外耳道形成過程における先天異常は, 小耳 症に代表されるように他の奇形も合併することがあり， 第 I 咽頭溝に由来するこれら病変には臨床的対応へのコ ンセンサスが要求される.

\section{参考文献}

1) Behrman RE, Kliegman RM and Jenson HB (Eds.) : Nelson Text Book of Pediatrics. 17th edition. Saunders, Philadelphia Pennysylvania, 2004.

2) McCarthy JG : Plastic Surgery. Sanders, Philadelphia, 1998.

3) Achauer BM, Eriksson E and Guyuron B : Plastic Surgery. Mosby, S. Louis, 2000.
4) Moore KL and Persaud TVN：ムーア人体発生学 第 6 版. 背口春道（監訳），医歯薬出版，東京， 2001.

5) Schuknecht HF : Congenital aural atresia. Laryngoscope :908 $\sim 917,1989$.

6) Ombredanne $M$ and Porte $L$ : Cholesteatome primitif de la caisse et aplasie mineure. Ann Otolaryngol $79: 427 \sim 430$, 1962.

7) Peron DL and Schuknecht HF : Congenital cholesteatomata with other anomalies. Arch Otolaryngol 101:498 505, 1975.

8) Nishimura $Y$, Minatogawa $T$ and Kumoi $T$ : Intractable retroauricular abscess associated with microtia and aural atresia-some views in relation to congenital cholesteatoma and microtia. Ann Plast Surg $23: 74 \sim 80,1989$.

9) Cole RR and Jahrsdoerfer RA : The risk of cholesteatoma in congenital aural stenosis. Laryngoscope 100:576 578, 1990.

10) Shah RK : External auditory canal atresia. eMedicine Sept. 21, 2006.

11）山根英雄：先天性外耳道閉鎖症への対応一耳鼻咽喉科医の ジレンマー. 耳鼻臨床 $98: 907 \sim 914,2005$.

12) Altmann $F$ : Congenital aural atresia of the ear in man and animals. Ann Otol Rhinol Laryngol 65:824 858, 1955.

13) De La Cruz A, Linthicum $F$ and Luxford $W$ : Congenital atresia of the external auditory canal. Laryngoscope $95: 421 \sim 427$, 1985.

14) Aronshon RS, Batsakis JG, Rice DH, et al. : Anomalies of the first branchial cleft. Arch Otolaryngol $102: 737 \sim 740,1976$.

15) Ford GR, Balakrishnan A, Evans JNG, et al. : Branchial cleft and pouch anomalies. J Laryngol Otol $106: 137 \sim 143,1992$.

16) Blevins NH, Byahatti SV and Karmody CS : External auditory canal duplication anomalies associated with congenital aural atresia. J Laryngol Otol $117: 32 \sim$ 38, 2003.

17) Jahrsdoerfer RA, yeakley JW, Aquilar EA, et al. : Grading system for the selection of patients with congenital aural atresia. Am J Otol $13: 6 \sim 12,1992$.

18) Molony TB and De La Cruz A : Surgical approach to congenital atresia of the external auditory canal. Otolaryngol Head Neck Surg $103: 991 \sim 1001,1990$.

19) Yamane H, Sunami K, Takayama M, et al. : Application of modified transmastoid approach methods to congenital atresia of the external ear canal with middle ear infection. Acta Otolaryngol suppl $554: 38 \sim 44,2004$.

20) Jahrsdoerfer RA : Congenital atresia of the ear. Laryngoscope 88 (suppl. 13) : $1 \sim 48,1978$.

21) Linstrom CJ, Aziz $\mathrm{MH}$ and Romo T3rd : Unilateral and aural atresia in childhood: case selection and rehabilitation. J Otolarungol $24: 168 \sim 179,1995$.

別刷請求先 : 山根英雄

干545-8585 大阪市阿倍野区旭町1-4-3

大阪市立大学大学院医学研究科耳鼻咽喉病態学 